\title{
NATURAL HERITAGE AS A RESOURCE FOR TOURISM DEVELOPMENT IN THE POLISH CARPATHIANS
}

\author{
Marek Więckowski* \\ * Institute of Geography and Spatial Organization, Polish Academy of Sciences, Twarda 51/5, \\ 00-818 Warsaw, Poland, marekw@twarda.pan.pl
}

\begin{abstract}
Natural heritage as a resource for tourism development in the Polish Carpathians

The Carpathians Mountains have great natural potential and good conditions for favourable development of tourism and constitute one of the most important tourist regions in Poland. The aim of this study is to present the role of natural resources in the mountains for tourism development in the Carpathian Mountain area in Poland. The analyses presented concern the identification of the attraction of nature-based tourist attractions and their impact on tourism development. An analysis of tourismrelated regional development has been made concentrating especially on the fields of spatial organization and the functioning and creation of tourist attractions. A general attempt was made to conceptualize the given problem using existing scientific literature and field trips. The author proposes a conceptual model concerning factors affecting the nature-based attractiveness of the Carpathian Mountains to tourism. According to the author, in the Carpathians, there are many natural elements which serve as resources for tourism. Three of them are much more important than others and include: mountainous relief, water and landscape mostly protected by law. All of them are followed by weather conditions.
\end{abstract}

Key words: tourism, tourism attraction, national park, Carpathians, Poland, European Union

\section{INTRODUCTION}

The Carpathians have great natural potential and good conditions favourable to the development of tourism and there are many studies describing the successful development of tourism in this area (e.g. Warszyńska 1985, Groch and Kurek 1995, Ptaszycka-Jackowska and Baranowska-Janota 2003, Więckowski 2004 and 2010, Faracik et al. 2009, Zawilińska 2010 and Więckowski et al. 2012). Lying very much in the heart of East Central Europe, the Carpathians have extremely rich scenic and biodiversity resources that have not been significantly eroded by the modernisation of the last two centuries (Buza and Turnock 2004 and Zawilińska 2010). Tourism has been considered an important branch of the economy in the Carpathians for many decades now, and also as one that is often treated as the sole opportunity for socio-economic development. At the same time the Carpathian Mountains constitute one of the most important tourist regions in Poland. The two additional, traditional branches of the economy in this region are agriculture and forestry (Jabs and Affek 2019). In the Carpathian areas where different cultures mix, the cultural landscape also represents an interest for tourism, along with numerous historical monuments and urban patterns.

The Carpathians possess specific resources important for different forms of development. Local and regional development is strongly dependent on the natural resource base of the area and this is an important factor for the existence of tourist attractions. Natural heritage resources are gaining an ever-increasing use in tou- 
rism, acting in the service of both local and regional development. Sometimes this utilisation has proceeded at the expense of the ecological or socio-cultural environment, with this urgently calling for the achievement of sustainability in the further future. More generally, a need has arisen for a discussion and critical evaluation of governance, policy, planning, marketing, human mobilities and socio-economic dimensions as all linking up with the growing tourism industry, inter alia in the CEECs (Więckowski and Saarinen 2019). These kinds of problems are related to the mountainous tourist areas where nature plays a crucial role as a resource for development. The mountains influence the development of specific kinds of tourism in the Carpathians. The forms of contemporary tourism in these areas are first and foremost provided by various forms of nature-oriented, leisure, adventure, health (medical), transit, cultural, gastronomic and event-oriented tourism.

Nowadays, economies are characterised by a shift in the functional development of regions towards the services sector, including opportunities related to tourist development. It also appears that the natural environment is sensitive to changes wrought by human development. Maintaining the right balance between economic development and the preservation of a quality natural environment is becoming ever more difficult and important. The tourist industry is no exception here, as it walks a fine line between sustainable tourism and mass tourism.

\section{AIM AND METHODS OF THE STUDY}

The aim of this study is to present the role of natural resources in the mountains for tourism development in the Carpathians in Poland. The analyses presented concern the identification of the resources and attraction of nature-based tourist attractions and their impact on tourism development. A general attempt was made to conceptualize the given problem. This article examines the current state (the beginning of the $21^{\text {st }}$ century) of tourism development in the Carpathians, and in some cases its historical background and the perception of the changing tourist use of nature. Research for this paper was primarily conducted on the Polish side of the Carpathian Mountains. An analysis of tourism-related regional development has been made concentrating especially on the fields of spatial organization and functioning and the creation of tourist attractions. The complexity of the tourism processes provides some difficulties in understanding both the spatial and social process. It could also cause some problems in the interpretation of data. This leads us to the over- or underestimation of the scale and character of tourism traffic. The strict definition of tourism in the contemporary world is very difficult to establish due to the overlapping of social and spatial processes (Hall 2003). The WTO and the UN Statistical Commission define tourism as the activities of persons travelling to and staying in places outside their usual environment for not more than one consecutive year for leisure, business and other purposes not related to the exercise of an activity remunerated from within the place visited (UN WTO 2010).

Natural heritage as a tourist attraction was analyzed from:

a) scientific literature concerning the aspects of nature-based tourism, tourism in mountainous areas, tourism development in the Carpathians,

b) field works which has been taken in many scientific travels into different regions of the Polish Carpathians,

c) other information, mainly statistical data. 
Data constraints, together with the weak theoretical base really needed for a holistic approach, have contributed to the lack of research on tourism as a complete process in certain areas. The information presented in this paper has been derived from the existing national data on tourism (e.g. statistical data from the official national statistical institution - GUS, and national parks). The paper restricts its scope largely to evidence from secondary data, although clearly many surveys and nonofficial data ${ }^{1}$ were included.

\section{NATURAL RESOURCES AS TOURIST ATTRACTIONS}

One of the key issues, associated with the tourist function of each region is the one of tourist attractiveness. The environment is one of the most basic resources for tourism and a core element of tourism products (Wall and Mathieson 2006). It had been held previously that the tourist attractiveness of a place depends upon its tourist qualities or only upon the existing tourist infrastructure. According to the model of tourist attraction (Lew 1987, Leiper 1990 and Richards 2002) the force, with which a place attracts tourists does not depend uniquely upon its tourist qualities. The valuable natural landscape therefore possesses very considerable tourist potential, with the proviso that that potential, of itself, is not sufficient for tourism to actually develop. It is widely agreed that the organisation of tourist traffic, especially tourism promotion and services, are among important factors determining the tourist attractiveness of a place.

Nature-based tourism includes tourism in natural settings, tourism that focuses on specific elements of the natural environment, and tourism that is developed in order to conserve or protect natural areas (Hall and Boyd 2005). One of the most important conclusions of their work is that nature-based tourism and tourism development, needs to be located not just within the context of the success or otherwise of tourism, but, far more importantly, within the wider regional development context and broader economic, social, political and environmental concerns (Hall and Boyd 2005).

Natural heritage is defined as the legacy of natural features and intangible attributes encompassing the countryside and natural environment. It situates the development of tourism here within the rhetoric of state and national conservation and development goals, and also identifies several of the main challenges faced by local communities in the further development of nature-based tourism.

Nature has been one of the most important elements for tourism development. Since the ideas of nature conservation emerged over a century ago, national parks and other protected areas have been designated, interpreted, museumized, and labeled for the purposes of tourists and society (MacCannell 1976, Saarinen 2004 and Reinius and Fredman 2007). In many places, such areas have become tourism products that the industry promotes and sells as attractions. Their "touristification" is exemplified by the fact that national parks have become tourist icons with many countries promoting some of their parks as "must-see attractions". In some cases

\footnotetext{
${ }^{1}$ As with all studies on migration and tourism, the analysis in this paper is supported by a relatively poor and inconsistent base of underlying data and information. The problems with counting international migrants and measuring workers' remittances are notoriously difficult. Official estimates are known to contain very large errors in both overstating and understating actual flows. In Poland the lack of studies on mobility in past decades and a lack of accurate data were the results of the difficulty of collecting the information and the neglect of the importance of this process.
} 
the attraction to visit individual parks is as much a product of marketing as it is of accessibility. In other cases, the uniqueness of places is often the sole reason why tourists visit them (Boyd 2004, p. 473). Tourism played an increasingly important role throughout the $20^{\text {th }}$ century, with the development of diverse infrastructures to attract this financial potential. This phenomenon implies a major paradox for the park, due to the simultaneous presence of highly endemic zones (therefore of strong ecological interest) and tourist zones (therefore of strong economic interest). For more than a century, the physical environment in the countryside has been perceived as scenery, a view or a perceptive sensation, which in addition was idealised, partly under the influence of the Romantic movement. "Nature was largely equated with leisure and pleasure - tourism, an exciting spectacle and visual respite" (Green 1990, p. 6).

Special attention to nature has been given to the mountainous areas. According to Nordregio (2004) the main values of European mountains are: headwaters of water resources required for agriculture, housing and industry, centres of biodiversity, cultural and ethnic diversity, tourism and recreation and reserves of valuable ecosystems that are sensitive to environmental change. However, the most important current problem in mountain areas in Europe is the preservation of the natural resource of the area, which is a precondition for maintaining a satisfactory environment and the economic importance of the mountains. The mountains embody the idea of peace, leisure and tradition (Corrado 2010). Nepal and Chipeniuk (2005) discuss six mountain-specific resource characteristics, which include diversity, marginality, difficulty of access, fragility, niche and aesthetics.

This increases environmental risks and entails a need for active management and the taking of decisions that cannot fully accommodate the expectations of tourists and conservationists that are often conflicting or mutually exclusive. Tourism based on the quality of the environment is particularly susceptible to damage to its very foundation, i.e. the natural environment itself (Mathieson and Wall 1982). Exploitation leads to a lower quality of the environment as a whole or of its parts and even to the disappearance of its valuable features.

\section{NATURAL POTENTIAL FOR TOURISM DEVELOPMENT IN THE CARPATHIANS}

\section{General conditions}

The Carpathians retain high aesthetic amenity values because of the various mountain landscapes and because they are relatively underdeveloped in relation to cities and industrial regions. Such high natural values serve as the basis for the development of nature-based tourism as well as other types of tourism and leisure development (e.g. skiing). From the very beginning, the natural environment has been the focus of attention in the Carpathians and it remains the principal attraction for visitors despite the numerous changes that society has undergone since that time. As Ford (2002) has explained there was a growing interest in the Carpathians as travellers from the more industrialised parts of Europe took advantage of the comforts of rail travel to reach a distant mountain region and to escape from modern civilisation in an area where the 'glamour of the Middle Ages' still persisted. Tourism was integrated with nature conservation from a very early stage of the national park movement (Zawilińska 2010 and Więckowski 2013 and 2018). In Carpathians the aesthetic values of nature for tourism and recreation were among 
profound motivations behind the process of establishing the first national parks before World War II.

Among the Carpathian ranges, the Tatra Mountains stand out with their strong symbolism, deep establishment in culture and tradition, strong brand and a market position that has been built up over more than 200 years. Other mountain ranges with outstanding environmental qualities attracting visitors include the Babia Góra massif, the Pieniny and Bieszczady ranges. Initially a health spa established in 1886, Zakopane became an important centre for mountain expeditions (Turnock 2006) and it was also the birthplace of Polish skiing with the formation of the skiing association in 1907 and the provision of a voluntary mountain rescue service in 1909. It was also seen as a cultural centre and symbol of Polish national unity prior to 1914. Moreover in 1889 the entire estate became the property of Count Zamoyski who eventually (1924) established a national foundation leading to the present Tatra National Park. For decades now, the town of Zakopane and the Tatra Mountains have been kept trendy through skilful advertising and cryptoadvertising, including in TV shows and movies, daily newspapers, web portals, through celebrity appearances in tourist spots, etc. The image of the Tatras is present in school education from the lowest grades and used as a symbol of mountains in general, of high mountains, of the highest Polish mountains and of the most beautiful Polish mountains. The mountains are relatively close to Krakow, Poland's second largest city, and to Upper Silesia, which has Poland's largest urban population (Więckowski et al. 2012).

Structural changes related to tourism have been visibly present in the development of tourism during the last two decades and especially in the last decade. On a general level, these changes are related to wider shifts in consumption and economic production that are often described as moving from Fordist production towards post-Fordist production and the related new methods of consumption, but in Poland changes from a socialist economy to a post-socialist one are the most important (Riley 2000). The functioning of tourism in Poland is mainly associated with the processes of transformation, integration, globalisation and modernisation. The capacity for developing tourism is decisively influenced by the general conditions, endogenous potential and path dependence. The primary impact on the functioning of tourism is exerted by the change of mobility of society (due to an increase in wealth, leisure time, and needs, as well as fashion linked with the desire to go on tourist trips). The new tourism represents rather a new type of tourism product with increasing flexibility, individuality, hybridity and activity, rather than a specific form of tourism or tourism activity. Nature-based tourism needs the same infrastructure nowadays as other tourism types. This view is supported by Misiura who stated that to be successful in tourism, "heritage attractions or other heritage consumer brands must appeal to the aspirations, needs, and motivations of prospective and regular customers" (Misiura 2006, p. 81).

Many authors have presented the essence of the tourist function and its diversity and the development of tourism space in the Carpathians (Jackowski 1981, Warszyńska 1985, Groch and Kurek 1995 and Więckowski 2002 and 2004). From the point of view of tourism development in the Carpathians, the general conditions of tourism space management turned out to be significant (Ptaszycka-Jackowska 2007), competition factors (Kurek and Mika 2008) and geopolitical factors (Więckowski 2004, Kurek 2008 and Faracik et al. 2009). Some authors emphasized the issue of the distribution of accommodation base showing concentration in the 
most attractive regions, such as the Tatra, Pieniny, Beskid Sądecki and Bieszczady Mountains (Riley 2000 and Więckowski 2002 and 2004). Guzik and Kołoś (2003) showed the importance of access to health resorts and their impact on the use of water resources, while Michniak et al. (2014), Michniak et al. (2015), Więckowski et al. (2012 and 2014), showed the importance of accessibility to natural elements and the main aspects related to demonstrating the importance of accessibility for the functioning and development of tourism.

After analysis of the scientific literature the most important factors influencing the tourist attractiveness of the Carpathian Mountains are summarised in Fig. 1.

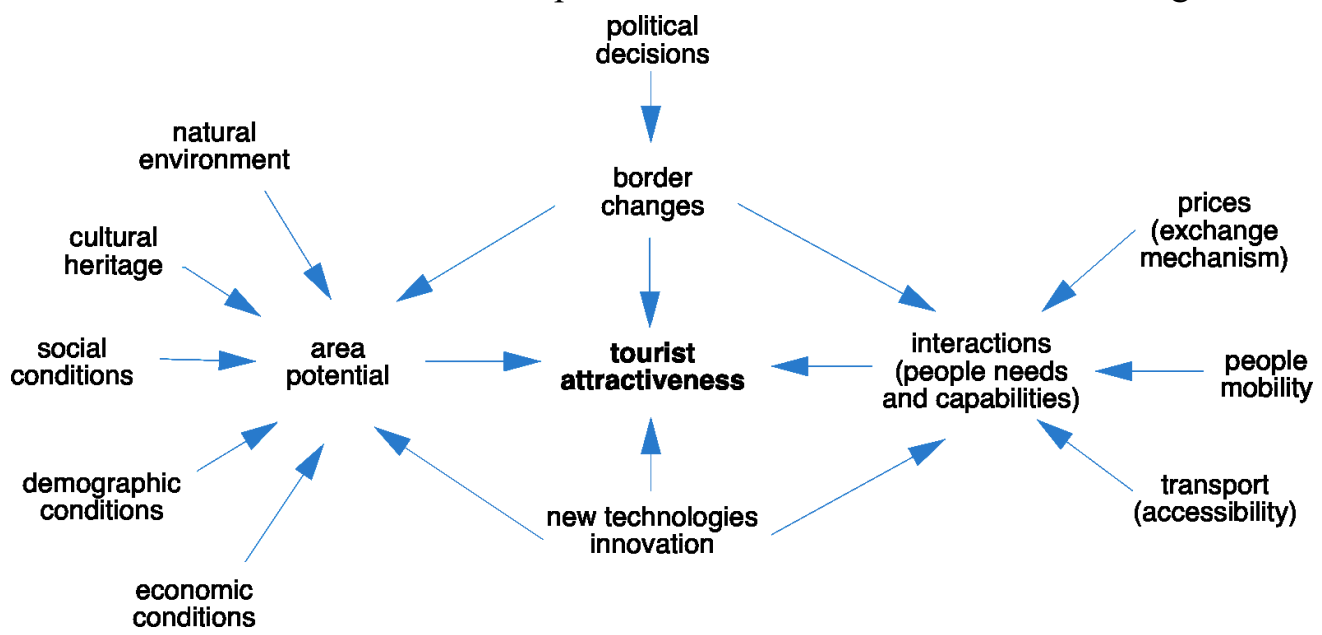

Fig. 1. Factors affecting the attractiveness of the Carpathian Mountains to the tourists taking into account their location along the national border

Source: Own elaboration.

It is often thought that certain landscapes, buildings or monuments express or represent a nation. Since the late $20^{\text {th }}$ century, however, landscapes have been widely regarded as common property, "a kind of a national asset" to use the words of Wordsworth. Numerous areas, i.e. landscapes and individual features, have attained, or lost - depending on current trends - a cult status and have even become national symbols. In a country that consists mostly of lowlands the Tatras play a very special role as Poland's "most mountainous" landscape and a national icon. The fact that the Carpathian Mountains account for just $6 \%$ of the country's territory makes them different and unique, and their environment becomes attractive from a tourist's point of view. Many of their natural features, such as the national parks and individual peaks, have gone beyond the simple status as tourist attractions and achieved a status as national icons. Alongside the Tatras other important areas of attraction include the Pieniny range (with its Mt. Trzy Korony and the Dunajec river gap) and the somewhat inaccessible Mt. Babia Góra, the highest peak of the Beskidy range, that offers a truly magnificent panorama, which connoisseurs appreciate, particularly at dawn. The remote Bieszczady range also has an iconic status with an aura of wilderness, emptiness and a refuge for those who want to escape from life. This was additionally fuelled by the presence of a heavily guarded Soviet border that cut the mountains in half after the Second World War. Attempts 
were also made to create a similar atmosphere in other eastern Beskidy ranges and in the Beskid Niski range, but that only sufficed to attract the most avid among hikers and create a market for second homes among Varsovians and, during the last 20 years, inhabitants of other cities, notably Rzeszów.

\section{NATURE AS A RESOURCE FOR TOURISM DEVELOPMENT IN THE POLISH CARPATHIANS}

In the Carpathians, there are many natural elements which serve as resources for tourism. Three of them are much more important than others and include: mountainous reliefs, water and general landscapes mostly protected by law. All of them are followed by weather conditions which are important as climatic variations and seasonal changes, leading to a greater tendency for tourists to take holiday during the summer (e.g. for hikers), although in winter (e.g. for skiers), and in general as stimulus climate for both leisure and treatment (e.g. spas). There is some tourist activity going on at nearly all times of year, but seasonality matters with peaks in summer and winter (Faracik et al 2009 and Więckowski et al. 2012 and 2014). These peaks have been observed to extend and shift, i.e. the summer season extends towards the autumn (into October) and the winter season lasts until spring (April) - Krzesiwo (2014). Weekend and bank holiday trips have been growing in importance.

While the natural Carpathian environment offers the right conditions for a variety of types of tourism, it particularly favours hiking, climbing and skiing. Recent additions to these traditional activities include such types of qualified tourism as mountain biking, cycling, paragliding and mountain kayaking, as well as an increase in horse-riding, and also recently, quad riding. In the literature, there are also preferences regarding types of tourism: the most popular forms of tourism in the Carpathians were cognitive tourism (including sightseeing and nature) as well as qualified tourism (walking, cycling, water and winter sports - strongly related to natural resources) and leisure (Więckowski et al. 2012).

\section{Mountains and mountainous relief}

Mountains are the primary tourist magnet in the area. Peaks and summit, passes and mountain saddles are to found in these mountains as the main attraction for mountaineers, hikers and other tourist coming to the Carpathians. They offer panoramic views e.g. from Babia Góra (Mocior et al. 2012), Rysy, Kasprowy Wierch, Turbacz and Tarnica (Szpara 2016). Many summits are also tourist attractions and are regarded as tourist symbols with a high national identity (e.g. Giewont, Babia Góra, Trzy Korony - Więckowski et al. 2012). There are many river gorges and valleys. The most beautiful parts of these areas are used by rafting, kayaking and walking. Also the highest parts of the mountain are of particular importance for mountain huts (Więckowski 2002 and 2004).

High snow cover and rugged mountain relief, as well as other factors enhancing the aesthetics of the region have been good factors for the development of ski and winter tourism. The natural conditions and spatial proximity of large urban centers are of fundamental importance for the development of ski tourism in the Polish Carpathians. In the group of natural conditions, climatic conditions and surface formation are of particular importance (Krzesiwo and Mika 2011 and Krzesiwo 2014). 


\section{Water}

In the Polish Carpathians there are favourable conditions for swimming in several reservoirs and rivers during the summer season. Mountain rivers, mainly the Dunajec and Poprad, have been used for kayaking and rafting. Water sports are present on most of the artificial lakes in the locality, including the most attractive of them, i.e. the Solińskie, Czorsztyńskie and Żywieckie lakes. Mineral waters provided the basis for the establishment of a number of spas that have been drawing visitors for the last two centuries. Curative waters were used for treatments, including carbonate waters and, to a lesser extent, also sodium and sulphite waters. There are also carbonate-chloride-sodium waters with compounds of arsenic present in the area and these are unique at a European scale. The largest spas are located in the Beskid Sądecki range (e.g. Krynica-Zdrój and Piwniczna-Zdrój) - Mika and Pawlusiński (2006) and Groch and Kurek (1995). Traditional spa tourism is growing where mineral springs occur, but a still underestimated wellness type of development has recently supplemented this (Skała et. al 2011). Recently, thermal spas pools and aqua parks have become trendy and a number of them have been built in recent years, e.g. in Bukowina Tatrzańska, Poronin, Zakopane (Więckowski et al. 2012) and Chochołów.

\section{Landscape mostly protected by law}

In the early $20^{\text {th }}$ century, the Carpathians became very important in relation to tourism and nature conservation activity (Więckowski 2013 and 2018). The environment of the Carpathians is very diverse, and is considered to be one of the most interesting in Europe. Many protected nature areas of both domestic and international importance have been established here. The Carpathians in Poland now have 6 National Parks, 13 Landscape Parks, more than 210 Nature Reserves, and many more minor areas where nature is protected by law. The Pieniny Mountains, taking in the two countries' parks of this name, began cooperating in 1932 through the creation of Europe's first transboundary protected area between two countries. There are now three national parks which are international parks situated on both sides of the state border (Tatra NP, Bieszczadzki NP and Pieniński NP) and two International Biosphere Reserves (of the Tatra Mts. and the Eastern Carpathians), and in the immediate vicinity there is another one (Babia Góra) - Więckowski (2004 and 2018) and Zawilińska and Mika (2013). National and landscape parks are of great meaning to the development of tourism in Carpathians (Więckowski 2004, 2010, 2013 and 2018, Zawilińska 2010, Mika et al. 2015 and Miazek 2020). Increasing benefits are noticed especially in the tourism sector as well as in related services (Zawilińska and Mika 2013), which is of special attention in borderland and mountainous areas (Więckowski 2013 and 2018). The opportunity to develop sustainable tourism in landscape parks (Zawilińska 2010) and in the Carpathians in general (Ptaszycka-Jackowska and Baranowska-Janota 2003, WarszyńskaJackowska, ed. 2007 and Mika 2014) is also being shown. Governance is of particular importance in the sustainable development of tourism (Zawilińska 2016).

In the countryside and in areas of outstanding natural beauty, countryside and nature-based tourism develops, with agritourism and eco-tourism in particular (Szpara 2011, Dorocki et al. 2016, Bajgier-Kowalska et al. 2017 and BajgierKowalska and Tracz 2019). Eco-tourism remains a minor phenomenon, a fact which can primarily be attributed to: consumerist attitudes towards tourist attractions on the part of both tourists and tourist organisers; low environmental aware- 
ness; and low demand for education during holiday time. Based on natural conditions, second homes as a new phenomenon use the natural resources of the mountains and the proximity of national parks as factors of attractiveness (Mika 2013 and Mika and Petko 2015).

\section{TOURISM TRAFFIC, CHANGES AND CONFLICTS IN TOURISM SPACE}

Tourism space is non-continuous given its relationship to phenomena creating strong and extensive systems of interconnections. It functions in places that are distant from one another and characterised by seasonality and a cyclical nature. The constant change would seem to be a feature of most tourist destinations, not least as the creation and development of spaces for tourism are seen to reflect wider political, economic and social processes often driven non-locally, if manifesting themselves very locally indeed (Więckowski and Saarinen 2019).

The development of tourism has brought a number of permanent features into the landscape. Ski resorts and spas are associated with accommodation and catering facilities, ski lifts and pistes, as well as tourist paths, etc. (Mika 2009 and Bučeková et al. 2019). Along the new and permanent features of a stationary nature (e.g. hotels, paths, bridges and viewing towers) there are some movable features that inhabit the landscape on a temporary basis, such as the rafts floating down the Dunajec River. As a result the Carpathians include both observable landscapes with 'traces' of human activity, i.e. the cultural landscape, and landscapes without such traces.

As has already been mentioned, the Carpathians are one of the most important tourist regions in Poland. Among the two million visitors they attract every year more than 85 per cent are Poles. One of the most important tourist regions in Poland - still nowadays (even border opening process) strong national effect. These figures come from official statistics alone and fail to take account of the between one and two million tourists who seek accommodation outside of pensions, hotels and hostels.

Tourist traffic in the Carpathians is concentrated in the most attractive localities. The centres of such concentrations are in the biggest towns e.g. Zakopane, Wisła, Ustron and Krynica-Zdrój. The majority of tourists come to the Tatras and their vicinity. The main tourist destinations in the Carpathians are National Parks (Więckowski et al. 2012, Miazek 2020) - see Tab. 1. Poland's number one natural attraction - the Tatra Mountains (Tatrzański) National Park - alone receives around 3,5 million visitors ${ }^{2}$ a year (Ochrona Środowiska 2018), The Pieniny National Park receives almost 900,000 visitors annually (Ochrona Środowiska 2018). Tourist traffic has been focusing on and around the Tatras (mainly in Zakopane) for more than 100 years.

During the peak summer season, the Tatra National Park is so full of professional, amateur and leisure tourists that it can take long queuing to climb the popular Mt. Giewont, to get to the shore of the Morskie Oko lake, to enter some of the Tatra caves or even to take a raft down the Dunajec river gap. This negates the main reason that attracts visitors to these destinations, i.e. their need to experience

\footnotetext{
${ }^{2}$ The number of visitors in this case concerns all entrance to the park which include sometimes the same tourist entering to the park in different days.
} 
the unique qualities of nature, while nature itself comes under a huge amount of "anthropopressure" that causes serious conflicts.

Tab.1. Number of visitors in national parks in the Polish Carpathians (in thous.)

\begin{tabular}{lcc}
\hline National park & Visitors in 2010 & Visitors in 2017 \\
\hline Babia Góra National Park & 54 & 83 \\
Bieszczady National Park & 280 & 513 \\
Gorce National Park & 60 & 90 \\
Magura National Park & 50 & 50 \\
Pieniny National Park & 603 & 898 \\
Tatra National Park & 2002 & 3779 \\
\hline
\end{tabular}

Source: Ochrona Środowiska GUS, 2011 (tab. 9. 193), 2018 (tab. 9. 168).

At the same time, however, concerns about tourism "overcrowding" in many areas as a result of such promotion has provoked increasingly confrontational protest over the last several years. The excessive concentration of tourist traffic, known as "overtourism", leads to over-crowding in attractive locations, overadvertising and aggressive commercialisation, which all work to lower the aesthetic quality of tourists' experiences, and results in the degradation of natural and cultural resources.

The presence of increasing numbers of tourists at popular destinations throughout the world has led to conflict with and complaints from residents concerned that such influxes were rendering their homes impossible to live in. The most significant conflict existing in the Carpathian Mountains divides the tourist industry and the natural environment. National parks and other protected areas, including nature reserves and landscape parks, tend to contain the most attractive tourist areas. In many cases a strong tourist demand drives the development of the tourist infrastructure and of tourist traffic.

The conflict between nature conservation and tourism, which started as early as in the $19^{\text {th }}$ century, is visible in many regions. Legal protection of nature started relatively early, especially where it was needed due to excessive and uncontrolled tourist traffic, but finding the golden mean that would reconcile the needs of nature protection and the development of tourism has proven elusive and sometimes an outright impossibility. In this context it is interesting to look at the densities of tourist traffic per square kilometre or per kilometre of tourist path. In the most popular national parks there are more than 10 thousand visitors per square kilometre (Tatra NP) and even more than 25 thousand visitors per square kilometre (Pieniny NP) - Ochrona Środowiska (2018). Considering that most of national park territo-

\footnotetext{
${ }^{3}$ An official definition also appeared, which reads: "the impact of tourism on a destination, or parts thereof, that excessively influences perceived quality of life of citizens and/or quality of visitors' experiences in a negative way" (UNWTO 2018).
} 
ries are excluded from tourism, the scale of traffic on marked paths can only be imagined. National parks are of great meaning to the socio-economic development of municipalities in Poland. Increasing benefits are noticed especially in the tourism sector as well as in related services (Zawilińska and Mika 2013 and Mika et al. 2015).

There are still great reserves for the development of tourism and greater dispersion of tourist traffic is important, not just to inject more economic growth in certain tourist areas, but also to relieve the congested regions. New opportunities have also appeared due to the opening of national borders and access to the entire Carpathian Mountain chain.

\section{BASIC APPROACH ON TRANSBOUNDARY ISSUES}

The location of much of the Polish Carpathian Mountains along the country's southern border also plays its role in determining their attractiveness and the related development of the tourist industry (Więckowski 2002 and 2004, PtaszyckaJackowska and Baranowska-Janota 2003, Lewkowicz 2011 and Więckowski et al. 2012).

During the long period, when the Polish-Czechoslovak (currently Polish-Slovak and Polish-Czech) border constituted an impenetrable spatial barrier to tourism, it contributed to minimising the change in the natural environment by impeding the development of areas adjacent to the border, some of which were even explicitly sealed-off. When the border was eventually opened (Szpara 2003 and Więckowski 2004), these areas could boast both a quality environment and a variety of tourist attractions increased by those located across the border in the other country (Więckowski 2010 and Zawilińska and Mika 2013).

The use the potential of resources, symbolism and transboundary integration (via the place-based approach). This is particularly true of those working to develop regional projects, who may mobilise tourism as a "place-making instrument". As a consequence, we observe tourism's use of space in the creation of local or regional poles of growth and regional and cross-border competition as a development factor in tourist reception areas (Więckowski 2010 and Faracik 2012).

Changes in the socio-economic and political environment of Slovakia after 1989 affected the economy and the way of life of the population. In regions attractive to tourists, and in their immediate vicinity land has become a commodity. In contrast, the environmental impacts of tourist urbanisation for residents are predominantly negative. This is mainly related to the visual and functional disruption of the landscape, and the overall environment in which residents live (Petrikovičová et. al. 2019). Tourist clusters in Slovakia as a tool for the improvement of regional competitiveness is the main topic of other studies, e.g. Székely (2014) and Cuka et al. (2012). There are favourable preconditions for the development of various kinds of tourism in Slovakia. The centre and north of the country are mountainous (the Carpathians) - Michniak (2016).

\section{DISCUSSION AND CONCLUSIONS}

Nature in mountain areas is a strong attractor that acts as an inspiration to sports, hiking and which serves as decoration. National parks and specific mountain features (peaks, valleys and lakes) have developed cult statuses, often as na- 
tional symbols. Many of these symbols have been awarded legal protection in national parks, of which Poland has six in the Carpathian Mountains. The Carpathians seem even more protected than other mountain ranges in Europe. In the Carpathians we observe a spatial enlargement - spillover of the tourist centre. The mountains have become more segmented and hybridised in form before diversifying. In the Carpathians we observe also the museumification of symbolic nature and strong nature protection. In peripheral regions, including border regions such as the Carpathian Mountains, it is difficult to change a development path (Hassink 2005). This is also reflected in the landscape. The concept of a mountain landscape entails leisure, relaxation and visual consumption. Each such landscape is also a place of remembrance and is temporary in character. Ingold (1993) says that events in the present assume a form of retention of the past and force a projection into the future. The Carpathian landscape is partly "fossilised" within protected areas, but it is changing just outside. There is a considerable pressure for the development of housing, holiday homes and tourist infrastructure in adjacent areas (Mika 2012).

In the Polish Carpathians the most popular attractions are found in the Tatras (Mt. Giewont, lake Morskie Oko, Mt. Kasprowy Wierch and the Kościeliska valley), followed by the Pieniny range (rafting on the Dunajec river, Mt. Trzy Korony) and the Bieszczady range (e.g. the Połonina Wetllińska glade). Each of these sites is visited by at least several hundreds of thousands of people every year, while the Tatra National Park has approximately three million visitors. Among the many factors driving this dense traffic, the uniqueness of these sites must be seen as the most important. This causes a considerable "anthropopressure", which is a problem that has been plaguing the Carpathians for more than one hundred years. Nowadays we have new antropopressure (settlements and tourism) due to the growth in the number of people, their increasing mobility (tourism movement and people in transit), and due to the growth of facilities and accessibility to valuable natural areas, even close to the national border with Slovakia. The issue of "anthropopressure" is growing, as the phenomenon is increasing as a result of consumerist attitudes driven by the media and by advertising. Tourist space develops in those locations where the area is attractive for tourists (e.g. thanks to attractions being associated with the mountains, elements of nature, a boundary, a peripheral location). It can be concluded that the development of tourism in the Carpathians is above all dependent on the presence of tourist attractions. One of the most important tourist attractions in the Carpathians is the natural environment. In this paper the influence of the most important elements affecting the tourist attractiveness of a mountainous area have been presented. Tourism in the Carpathians is based upon an attractive nature (including national parks) and a cultural heritage. Additionally, regions develop new ski-centres and new event tourism, both at a national and international (even transboundary) level.

In the years to come the development of transport and the increase in the amount of free time, etc. will lead to more intensive competition between regions both in terms of the seeking out of investors with a view to expanding tourist infrastructure (as well as other, e.g. transport - infrastructure) in order to ensure changes in the function performed by respective centres and regions, and also in terms of attracting tourists. One specific issue is that the areas in question still have large reserves for the development of tourism at their disposal and broader dispersion of tourist traffic is essential, not only for the economic growth of rarely-visited areas, but also for a reduction in congestion in those in which traffic is excessive (e.g. 
huge difference in tourist traffic in national parks). The very fact that the border area had been underdeveloped, depopulated, etc. may constitute a positive element, since a lack or relatively low intensity of settlement processes and related production activities (agriculture and manufacturing) could entail an improvement in the environmental conditions in a given region over a defined period. Such areas have frequently gained nature-based attractiveness, and legally-protected natural areas have been established there, something that enhances tourist attractiveness in virtually every case. As the importance of tourism for the life of societies and their economies increases at every level from local, to regional and national, to the point of becoming one of the most important industries of such regions as the Carpathian Mountains, it is also an ever more important subject of study.

The Author wishes to thank the anonymous reviewers for their valuable comments and suggestions.

\section{REFERENCES}

BAJGIER-KOWALSKA, M., TRACZ, M., ULISZAK, R. (2017). Modeling the state of agritourism in the Malopolska region of Poland. Tourism Geographies, 19, 502-524. DOI: 10.1080/ 14616688.2017.1300935.

BAJGIER-KOWALSKA M., TRACZ, M. (2019). Models of agritourism business development in the Polish Carpathians. Studies of the Industrial Geography Commission of the Polish Geographical Society, 33, 188-200. DOI: https://doi.org/10.24917/ 20801653.333.13.

BOYD, S. (2004). National parks: Wilderness and culture. In Lew, A., Hall, M., Williams, A., eds. A companion to tourism, Malden (Blackwell), pp. 473-483.

BUČEKOVÁ, I., ERBERT, L., KLOBUČNÍK, M. (2019). Klasifikácia lyžiarskych stredísk na Slovensku. Geografický časopis, 71, 363-382.

BUZA, M., TURNOCK, D. (2004). A research note: Planning for the Carpathians. Geojournal, 68, 135-142.

CORRADO, F. (2010). Fragile areas in the Alpine region: A reading between innovation and marginality. Journal of Alpine Research, 98-3, 1-10.

ČUKA, P., NÉMETHYOVÁ, B., MIŠĆÍKOVÁ, B. (2012). Short profile of the specific functioning of tourism clusters in Slovakia. Current Issues of Tourism Research, 2, 3239.

DOROCKI, S., SZYMAŃSKA, A. I., ZDON-KORZENIOWSKA, M. (2016). Agricultural tourism farms in Poland: How the farmers improve their businesses - A case study. Understanding Innovation in Emerging Economic Spaces: Global and Local Actors. Networks and Embeddedness, 15, 247-248.

FARACIK, R., KUREK, W., MIKA, M., PAWLUSIŃSKI, R. (2009). Turystyka w Karpatach Polskich w świetle współczesnych kierunków rozwoju. In Domański, B., Kurek, W., eds. Gospodarka i przestrzeń. Kraków (Instytut Geografii i Gospodarki Przestrzennej UJ), pp 77-98.

FARACIK, R. (2012). Granice polityczne a turystyka: wzajemne relacje na wybranych przykładach z Europy. In Sadowski P., ed. Rozwój turystyki kulturowej i przyrodniczej na pograniczu polsko-słowackim. Nowy Targ (Podhalańska Państwowa Wyższa Szkoła Zawodowa), pp. 11-17.

FORD, L. (2002). Relocating an idyll: How British travel writers presented the Carpathians 1862 - 1912, Journal of Travel \& Travel Writing, 2, 50-78.

GROCH, J., KUREK, W. (1995). Turystyka. In Warszyńska, J., ed. Karpaty Polskie. Kraków (UJ Kraków), pp. 265-300.

GREEN, N. (1990). The spectacle of nature. Manchaster (Manchaster University Press). 
GUZIK, R., KOŁOŚ, A. (2003). Evolution of accessibility in Carpathians Spa resorts between 1938 and 2000. In. Kurek, W., ed. Issues of tourism and health resort management, Prace Geograficzne, no. 111, Kraków (Instytut Geografii i Gospodarki Przestrzennej UJ, Wydawnictwo Uniwersytetu Jagiellońskiego), pp. 356-368.

HALL, C. M. (2003). Introduction to tourism: Dimensions and issues. Melbourne (Pearson Education).

HALL, C. M., BOYD, S., ed. (2005). Nature-based tourism in peripheral areas: Development or disaster? Aspects of Tourism 21. Clevedon (Channel View Publications).

HASSINK, R. (2005). How to unlock regional economies from path dependency? From learning region to learning cluster. European Planning Studies, 13, 521-535.

INGOLD, T. (1993). The temporality of the landscape. World Archeology, 25, 152-174.

JABS, Z. J., AFFEK, A. N. (2019), Dostępność rolnicza Beskidów. Przegląd Geograficzny, 91, 97-111.

JACKOWSKI, A. (1981). Typologia funkcjonalna miejscowości turystycznych. Na przykładzie województwa nowosądeckiego. Kraków (Uniwersytet Jagielloński).

KRZESIWO, K. (2014). Rozwój i funkcjonowanie stacji narciarskich $w$ polskich Karpatach. Kraków (IGIGP Uniwersytet Jagielloński).

KRZESIWO, K., MIKA, M. (2011). Ocena atrakcyjności turystycznej stacji narciarskich w świetle zagadnienia ich konkurencyjności - studium porównawcze Szczyrku i Białki Tatrzańskiej. Prace Geograficzne, 125, 95-110.

KUREK, W. (2008). Tourism in Polish Carpathians in the political transition time. In Wyrzykowski, J., ed. Conditions of the foreign tourist development in Central and Eastern Europe, tourism in geographical environment. Wrocław (Uniwersytet Wrocławski), pp. 295-302.

KUREK, W., MIKA, M. (2008). Miejscowości turystyczne w dobie konkurencji (na przykładzie Polskich Karpat). In Gołembski, W. G., ed. Turystyka jako czynnik wzrostu konkurencyjności regionów $w$ dobie globalizacji. Poznań (Wydawnictwo Akademii Ekonomicznej w Poznaniu), pp. 219-228.

LEIPER, N. (1990). Tourist attraction systems. Annals of Tourism Research, 17, 367-384.

LEW, A. (1987), A framework of tourist attraction research. Annals of Tourism Research, $14,553-575$.

LEWKOWICZ, Ł. (2011). Polsko-słowacka współpraca transgraniczna w regionie Tatr po 1918 roku. Sprawy Narodowościowe, 38, 195-207.

MacCANNELL, D. (1976). The tourist. A new theory of the leisure class. New York (Schocken Books Inc.).

MATHIESON, A., WALL, G. (1982). Tourism: Economic, physical and social impacts. London (Longman).

MIAZEK, P. (2020). Causes of variations in the scale of tourism in Polish national parks. Turyzm/Tourism, 30, 71-83.

MICHNIAK, D. (2016). Role of railway transport in tourism: Selected problems and examples in Slovakia. Quaestiones Geographicae, 35, 107-120.

MICHNIAK, D., WIĘCKOWSKI, M., KOMORNICKI, T., STĘPNIAK, M., ROSIK, P., ŚLESZYŃSKI, P. (2014). Analýza vplyvu investícií do cestnej infraštruktúry na rozvoj cestovného ruchu v pol'sko-slovenskom pohraničí. Ekonomicky časopis, 62, 540-554.

MICHNIAK, D., WIĘCKOWSKI, M., STĘPNIAK, M., ROSIK, P. (2015). The impact of selected planned motorways and expressways on the potential accessibility of the Polish -Slovak borderland with respect to tourism development. Moravian Geographical Reports, 1, 13-20.

MIKA, M. (2009). Ski tourism in the Polish Carpathians - present state and issues of development. Folia Geographica, 14, 198-208.

MIKA, M. (2012). Kierunki i cechy rozwoju drugich domów w polskich Karpatach w świetle stanu badań. Czasopismo Geograficzne, 83, 63-79.

MIKA, M. (2013). Spatial patterns of second homes development in the Polish Carpathians In Kozak, J., Ostapowicz, K., Bytnerowicz, A., Wyżga, B., eds. Integrating nature and 
society towards sustainability environmental science and engineering. BerlinHeidelberg (Springer Verlag).

MIKA, M. (2014). Zatożenia $i$ determinanty podtrzymywalności lokalnego rozwoju turystyki. Kraków (IGIGP Uniwersytet Jagielloński).

MIKA, M., PAWLUSIŃSKI, R. (2006). Some problems of the development of spa \& wellness services in the Polish Carpathian Mountains. In Wyrzykowski, J., ed. Conditions of the foreign tourist development in Central and Eastern Europe, Contemporary models of spa tourism, 9. Wrocław (Institute of Geography and Regional Development UW), pp. 61-73.

MIKA, M., PAWLUSINSKI, R., ZAWILIŃSKA, B. (2015). Park narodowy a gospodarka lokalna. Model relacji ekonomicznych na przykładzie Babiogórskiego Parku Narodowego. Kraków (IGIGP, Uniwersytet Jagielloński).

MIKA, M., PETKO, J. (2015). Drugie domy w otoczeniu Babiogórskiego Parku Narodowego: wybrane problemy rozwoju. In Durydiwka M., Duda-Gromada, K., eds. Przestrzeń $w$ turystyce: znaczenie $i$ wykorzystanie. Warsaw (Wydział Geografii i Studiów Regionalnych UW), pp. 325-332.

MISIURA, S. (2006). Heritage Marketing. Oxford (Elsevier).

MOCIOR, E., FRANCZAK, P., HIBNER, J., KRĄŻ, P., RECHCIŃSKI, M., TOKARCZYK, N. (2012). Efemeryczny krajobraz wschodu słońca jako czynnik motywujący turystów do nocnych wejść na Babią Górę. Problemy Ekologii Krajobrazu. Rekreacja w krajobrazach o wysokim potencjale. 34, 203-209.

NEPAL, K. S., CHIPENIUK, R. (2005). Mountain tourism: Toward a conceptual framework. Tourism Geographies, 7, 313-333.

NORDREGIO (2004). Mountain Areas in Europe: Analysis of mountain areas in UE member states, acceding and other European countries. Final report (European Commission contract), Nordic Centre for Spatial Development.

OCHRONA ŚRODOWISKA, GUS (2011). Główny Urząd Statystyczny, Warszawa.

OCHRONA ŚRODOWISKA, GUS (2018). Główny Urząd Statystyczny, Warszawa.

PETRIKOVIČOVÁ, L., KROGMANN, A., FIALOVÁ, D., SVORAD, A. (2019), Intensive tourist-related urbanisation impacts on a mountain village: The case study of Vel'ká Lomnica in Slovakia, Geographia Polonica, 92, 395-408.

PIERSON, P. (2004). Politics in time. Princeton (Princeton University Press).

PTASZYCKA-JACKOWSKA, D., ed. (2007). Gospodarowanie przestrzenią turystyczną w Karpatach Polskich. Polska przestrzeń turystyczna. Prace Geograficzne, 117, 99-112.

PTASZYCKA-JACKOWSKA, D., BARANOWSKA-JANOTA, M. (2003). Tourism within the Polish and Slovak transfrontier region. Prace Geograficzne, 111, 44-60.

REINIUS, W. S., FREDMAN, P. (2007). Protected areas as attractions, Annals of Tourism Research, 34, 839-854.

RICHARDS, G. (2002). Tourism attraction systems: exploring cultural behavior. Annals of Tourism Research, 29, 1048-1064.

RILEY, R. (2000). Embeddedness and the tourism industry in the Polish Southern Uplands. Social Processes as an Explanatory Framework. European Urban and Regional Studies, 7, 195-210.

SAARINEN, J. (2004). Tourism and touristic representations of nature. In Lew, A., Hall, M., Williams, A., eds. A companion to tourism. Malden (Blackwell), pp. 438-449.

SKAŁA, M., SZPARA, K., WĄTROBA, Ł. (2011). Turystyka w gminach uzdrowiskowych województwa podkarpackiego. In Rapacz, A., ed. Gospodarka turystyczna $w$ regionie. Przesiębiorstwo. Samorząd. Wspótpraca. Prace Naukowe Uniwersytetu Ekonomicznego we Wrocławiu. Wrocław (Wyd. Uniwersytetu Ekonomicznego), pp. 967-977.

SZÉKELY, V. (2014). From enthusiasm to scepticism: Tourism cluster initiatives and rural development in Slovakia. Studies in A gricultural Economics, 116, 74-81.

SZPARA, K. (2003). Tourist border crossing points as elements of trans border cooperation in the Polish Carpathians. Prace Geograficzne, 111, 217-226. 
SZPARA, K. (2011). Agroturystyka w Karpatach Polskich. Prace Geograficzne Uniwersytetu Jagiellońskiego, 125, 161-178.

SZPARA, K. (2016). Rozwój ruchu turystycznego. In Wolski J., ed. Bojkowszczyzna Zachodnia - wczoraj dziś i jutro, Monografie, 17. Warsaw (IGiPZ PAN), pp. 445-472.

TURNOCK, D. (2006). Settlement history and sustainability in the Carpathians in the eighteenth and nineteenth centuries. Review of Historical Geography and Toponomastics, 1, 31-60.

United Nations WTO (2010). International/recommendations for tourism statistics 2008. New York (United Nations WTO).

United Nations WTO (2018). Overtourism? Understanding and managing urban tourism growth beyond perceptions. Madrid. DOI: https://doi.org/10.18111/9789284419999.

WALL, G., MATHIESON, A. (2006). Tourism. Change, impacts and opportunities. New York (Pearson and Prentice Hall).

WARSZYŃSKA, J. (1985). Funkcja turystyczna Karpat Polskich. Folia Geographica, seria Geographica-Oeconomica, 18, 79-104.

WARSZYNSKA-JACKOWSKA, J., ed. (2007). Turystyka zrównoważona na obsza- rze Beskidów Zachodnich. Studium uwarunkowań i barier rozwoju. Kraków (IGSMiE PAN).

WIECKOWSKI, M. (2002). Development of the new tourist space of the Western Carpathian Mts. in the 1990s. Europa XXI, 7, 121-131.

WIĘCKOWSKI, M. (2004). Przyrodnicze uwarunkowania kształtowania się polskosłowackich więzi transgranicznych. Prace Geograficzne, 195. Warszawa (IGiPZ PAN).

WIECCKOWSKI, M. (2010). Tourism development in the borderlands of Poland. Geographia Polonica, 83, 67-81.

WIECCKOWSKI, M. (2013). Eco-frontier in the mountainous borderlands of Central Europe. The case of Polish border parks. Journal of Alpine Research / Revue de géographie alpine, 101. DOI: https://doi.org/10.4000/rga.2107.

WIĘCKOWSKI, M. (2018). Political borders under ecological control in the Polish borderlands. Geographia Polonica, 91, 127-138.

WIĘCKOWSKI, M., MICHNIAK, D., BEDNAREK-SZCZEPAŃSKA, M., CHRENKA, B., IRA, V., KOMORNICKI, T., ROSIK, P., STEPNIAK, M., SZÉKELY, V., ŚLESZYŃSKI， P., ŚWIĄTEK, D., WIŚNIEWSKI, R. (2012). Polish-Slovak borderland: Transport accessibility and tourism. Prace Geograficzne, 234. Warszawa (Instytut Geografii i Przestrzennego Zagospodarowania PAN).

WIECKOWSKI, M., MICHNIAK, D., BEDNAREK-SZCZEPAŃSKA, M., CHRENKA, B., IRA, V., KOMORNICKI, T., ROSIK, P., STEPNIAK, M., SZÉKELY, V., ŚLESZYŃSKI, P., ŚWIĄTEK, D., WIŚNIEWSKI, R. (2014). Road accessibility to tourist destinations of the Polish-Slovak borderland: 2010 - 2030 prediction and planning. Geographia Polonica, 87(2), 5-26.

WIĘCKOWSKI, M., SAARINEN, J. (2019). Tourism transitions, changes, and the creation of new spaces and places in Central-Eastern Europe. Geographia Polonica, 92, 369-377.

ZAWILIŃSKA, B. (2010). Możliwości rozwoju turystyki w parkach krajobrazowych Karpat Polskich $w$ świetle idei zrównoważonego rozwoju. Prace Doktorskie, Uniwersytet Ekonomiczny w Krakowie, Kraków.

ZAWILIŃSKA, B. (2016). Postawy społeczności lokalnych wobec parku narodowego i rozwoju turystyki na przykładzie miejscowości w otoczeniu Babiej Gór. Prace Geograficzne, 145, 7-30.

ZAWILIŃSKA B., MIKA, M. (2013). National parks and local development in Poland: A municipal perspective. Human Geographies - Journal of Studies and Research in Human Geography, 7, 43-52. 
Marek Wi ęckowski

\section{PRÍRODNÉ DEDIČSTVO AKO ZDROJ ROZVOJA CESTOVNÉHO RUCHU V POLSKÝCH KARPATOCH}

Ciel'om tohto článku je predstavit' úlohu prírodných zdrojov horských oblastí v rozvoji cestovného ruchu v oblasti Karpát na území Pol’ska. V článku boli identifikované prírodné turistické atraktivity a hodnotený ich vplyv na rozvoj cestovného ruchu. Okrem toho sa analyzoval rozvoj regiónov založený na rozvoji cestovného ruchu s osobitným zameraním na ich priestorovú organizáciu, fungovanie a vytváranie turisticky atraktívnych miest. V príspevku je tiež prezentovaný vplyv najdôležitejších prvkov na turistickú prít’ažlivost' horských oblastí.

Cestovný ruch je už niekol'ko desat'ročí dôležitým odvetvím hospodárstva v Karpatoch a tiež odvetvím, ktoré je často považované za jedinú príležitost' pre sociálno-ekonomický rozvoj. Karpaty sú jedným z najdôležitejších regiónov cestovného ruchu v Pol'sku. Cestovný ruch sa tu rozvíja a pohybuje na citlivej línii medzi udržatel'nost'ou a masovost'ou.

Hlavným turistickým magnetom v oblasti sú pohoria. Medzi karpatskými pohoriami vynikajú Tatry, a to svojou vel'kou symbolikou, hlbokým ukotvením v kultúre a tradícii, silnou značkou a trhovou pozíciou, ktorá sa buduje už vyše 200 rokov. K d'alším pohoriam s výnimočnými environmentálnymi kvalitami, ktoré prit’ahujú návštevníkov, patrí masív Babej hory (Babia Góra) a pohoria Pieniny a Bieszczady. Okrem návštev národných parkov existuje niekol'ko spôsobov, ako môže cestovný ruch preniknút' do prírodného prostredia, či už priamo ako ciel' alebo prostredníctvom využitia prírody na rozvoj rozsiahlej infraštruktúry.

Horské svahy a zimy so snehovou pokrývkou napomáhajú rozvoju lyžovania. Karpaty sú známe ako kolíska pol'skej horskej turistiky, kde si l'udia môžu užit' prírodu pešo, na koňoch, vozoch t’ahaných koňmi, na bicykli a v súčasnosti aj na štvorkolkách. Horské rieky, hlavne Dunajec a Poprad, sa využivajú na jazdu na kajaku a rafting. Vodné športy sú rozvinuté na väčšine umelých vodných nádrží v oblasti, vrátane tých najatraktívnejších Jezioro Solińskie, Jezioro Czorsztyńskie a Jezioro Żywieckie. Minerálne vody boli základom pre založenie viacerých kúpel'ných miest, ktoré prit’ahujú návštevníkov počas posledných dvoch storočí. Minerálne vody vrátane uhličitanových, v menšej miere aj sodíkových a siričitanových, sa používajú pri liečebných procedúrach. Vyskytujú sa tu tiež v európskom meradle jedinečné vody so zlúčeninami arzénu. Najväčšie kúpele sa nachádzajú v oblasti pohoria Beskid Sądecki (napr. Krynica-Zdrój a Piwniczna-Zdrój). V ostatnom období sa stali populárnymi termálne kúpaliská (Bukowina Tatrzańska, Poronin, Zakopané a Chochołów). Najatraktívnejšie miesta v pol'ských Karpatoch sa nachádzajú v Tatrách (vrch Giewont, jazero Morskie Oko, Kasprov vrch a Dolina Kościeliska), nasleduje pohorie Pieniny (splav rieky Dunajec, Tri Koruny) a pohorie Bieszczady (napr. mlyn Połonina Wetllińska). Každú z týchto lokalít každoročne navštevuje najmenej niekol'ko stotisíc l'udí, pričom v Tatranskom národnom parku sú to ročne približne tri milióny návštevníkov.

Karpaty si zachovávajú vysoké hodnoty estetickej kvality najmä vd'aka pestrosti horskej krajiny a aj preto, že sú relatívne málo rozvinuté v porovnaní s vel'kými mestami a priemyselnými regiónmi. Významné prírodné hodnoty sú základom rozvoja cestovného ruchu založeného na prírodnom prostredí, ako aj iných druhov cestovného ruchu a rekreácie (napr. lyžovanie, druhé bývanie). Cestovný ruch v týchto oblastiach má predovšetkým podobu rôzznych foriem prírodne orientovaného, rekreačného, liečebného, tranzitného a kultúrne i gastronomicky orientovaného a na organizované podujatia zameraného cestovného ruchu. 
